\title{
The gender gap in bank credit access
}

\author{
Pablo de Andrés ${ }^{a}$, Ricardo Gimeno ${ }^{\text {b, }}$, Ruth Mateos de Cabo ${ }^{c}$ \\ ${ }^{\text {a }}$ Universidad Autónoma de Madrid and ECGI, Spain \\ ${ }^{\mathrm{b}}$ Banco de España, Spain \\ ${ }^{\mathrm{c}}$ Universidad CEU San Pablo, Spain
}

\section{A R T I C L E I N F O}

\section{JEL codes:}

G32

J16

L25

M13

\section{Keywords:}

Gender discrimination

Credit demand

Credit access

Credit performance

Financing

\begin{abstract}
A B S T R A C T
We use a sample of over 80,000 Spanish companies started by a sole entrepreneur between 2004 and 2014, and distinguish between male and female entrepreneurs demand for credit, credit approval ratio, and credit performance. We find that female entrepreneurs who start a business are less likely to ask for a loan. Of the female entrepreneurs requesting a credit, the probability of obtaining one in the founding year is significantly lower than their male peers in the same industry. This lower credit access disappears over the subsequent years, once the company has a track record of profits and losses. We also observe that women-led companies that receive a loan in the founding year are less likely to default as compared to men-led companies. This superior performance disappears for subsequent years, coinciding with the disappearance of the lower credit access. Taking all these results together, we rule out both taste-based discrimination and statistical discrimination in the credit industry, and point to the possible presence of double standards which might be a consequence of implicit (unconscious) discrimination.
\end{abstract}

\section{Introduction}

In a market economy, the availability of and access to finance is a crucial element in the creation, development and survival of any enterprise (Marlow and Patton, 2005). Finance is particularly critical for small and young businesses (Beck and Demirguc-Kunt, 2006). For small businesses, bank lending is the key source of external financing (Berger and Udell, 2002). Any potential dysfunction of the lending channel, or any barrier or bias hindering the lending process will very negatively affect small business growth and survival, their employees, and ultimately the whole economy.

One potential bias is that, when seeking financing, women-led small businesses might experience greater difficulties than their men-led counterparts. This could be due to stereotypes portraying female entrepreneurs as less skilled and efficient (taste-based discrimination); to information-related frictions that ground the credit decision on the average characteristics of the group (statistical discrimination); or to the presence of unconscious biases (implicit discrimination / double standards). Undeniably, in any of these cases, women-led businesses would experience tougher credit access, which would have extremely negative consequences on business growth, employment, and the economy.

Extant research spotlights on both demand and supply sides of the credit market. From the demand side, Ongena and Popov (2016), using a survey across several countries, find female-owned firms apply for bank credit less often than male owned firms because they believe their request will not be approved. Treichel (2006) report similar results. Should this fear of rejection be strong, female

\footnotetext{
* Corresponding author.

E-mail address: ricardo.gimeno@bde.es (R. Gimeno).
} 
entrepreneurs might ask for another type of financing, which would explain the lower level of bank credit in female-owned businesses. Robb and Wolken (2002), Galli and Rossi (2016) and Moro et al. (2017) also report female entrepreneurs are less likely to request loans as compared to their male counterparts.

On the supply side, Beck et al. (2018) exploit the quasi-random assignment of borrowers to loan officers to find that borrowers matched to officers of the opposite sex are less likely to return for a second loan. The effect is greater when officers have little prior exposure to borrowers of the other gender and when officers have more discretion to act on their gender beliefs. However, the authors were unable to infer about the direction of bias. That is, whether officers benefit potential lender of the same gender or harm the other gender. Alesina et al. (2013) find evidence that women pay more for credit than men, although they do not find any evidence that female borrowers engage in more risk-taking behavior than men. The authors point to a kind of statistical discrimination that could be the cause of these findings; in other words, to certain risk factors that are not observable by econometricians but which are apparent to the lender. By contrast, Ongena and Popov (2015) do not find differences in interest rates, loan conditions and amounts, or the likelihood of refusal, and the same outcome is reported by Moro et al. (2017) in an EU survey, or Asiedu et al. (2012) in a survey of US Small business. Treichel (2006) report that loan refusal rates for male and female entrepreneurs are quite similar.

Extant research tries to establish a link between gender discrimination and credit access. Although it appears that female entrepreneurs face certain barriers related to their gender when requesting financing, it is very difficult to isolate the phenomenon, and to infer the causality, due to the many different variables involved (Ongena and Popov, 2015; Aristei and Gallo, 2016). There is still a clear lack of cumulative knowledge and a failure to adequately conceptualize and develop alternative theories. Yet the empirical field offers an opportunity to find explanations, drawing on more and richer data sets that would allow some perspective of the relationship between gender bias and credit access to be isolated. Efforts in this direction could help us to know the causes of this situation and propose measures designed to amend it. This would improve the efficiency of the banking system, reduce the financial restrictions that small businesses must face up to, and boost both economic and corporate growth.

In our paper, we deal with these problems using a very unique data set containing all bank loans requested and granted in Spain (CIRBE, the Spanish Credit Register data set) during the period 2004-2014, and matching said database with the businesses created each year (SABI), to see whether entrepreneurs sought a loan to begin their activity. In this way, we cover the entire population of new small businesses that demand and use bank financing to start their activity. These companies employ just one director and, therefore, it is possible to know their gender. Since this data set is composed of new firms for which there is no prior financial record -only a business plan in a specific industry- bank officers must ground the credit granting decision on the basis of other readily observable variables such as the entrepreneur's characteristics (e.g., gender), which might be used as a proxy of the new company's creditworthiness. In this context, gender is an objective measure, which is non-modifiable, and does not rely on suppositions.

Thus, using new firms without financial or risk historical records, we respond to Alesina et al. (2013) call to avoid, or at least greatly reduce, non-observable risk factors that are apparent to the lender but not to the econometrician. This allows us to focus the analysis on the link between credit access and gender. Of course, we are unable to isolate the relationship completely, although we can, however, rule out the existence of an ex-ante informational effect. Thus, information comes from the nature of the business, the capital provided by the entrepreneur, the specific time money is requested and, the hypothesis being tested, gender. In such circumstances, the existence of any kind of gender discrimination would curb the credit granted to female entrepreneurs.

Additionally, our research strategy is not restricted to a cross-section analysis. Since the granting of a loan has an ex-post informational effects, we adopt Cabral and Mata's (2003) dynamic approach to follow each business along its life cycle, and, especially, whether a business requests and is granted a loan or not, as well as the business's subsequent loan performance. This involves continuing to match both data sets throughout the period. Computationally, this proves demanding, since we commence with around 80,000 companies which we must later track among the whole population of loan demands, loan concessions and loan defaults, month by month over an 11-year period. However, this dynamic component of analysis is crucial vis-à-vis understanding the relationship between gender and credit access, since banks obtain a kind of risk profile of companies as they grow older, a profile they lacked when the firms set out. We think this dynamic analysis is key to correctly explaining the initial cross sections between gender and credit access and to identifying whether this is due to potential bias by credit institutions, or whether it is a result of the lower credit quality of entrepreneurs and their companies. To the best of our knowledge, this is the first time this kind of analysis has been carried out.

Initially, our estimations confirm that companies run by women are less likely to ask for a loan, as previous findings from the literature on the demand side have shown. Therefore, we concentrate our analyses on the subset of companies that requested a loan, effectively controlling for credit demand. On this group of companies, we estimate the likelihood of securing a loan, and find that female entrepreneurs suffer more financial restrictions than their male counterparts when starting a business. This difference is maintained for one further period (albeit marginally) and disappears after two years of activity, then remaining non-significant over the years. Specifically, the chances of a company being granted a loan at the start are $10 \%$ lower for female than for male entrepreneurs. After a year, this drops to roughly $6 \%$ and completely disappears after two years. This time allows banks to construct a profile of the firm and to gather more information that was unavailable when the company was created. The fact that this probability disappears after the second or subsequent years rules out the possibility that the difference stems from discrimination based on the lender's taste (Becker, 1957), since we would expect that adding new information about the business would not change the perceptions derived from preferences and cultural beliefs about gender that are pervasive and persistent.

Bias might then be consistent with statistical discrimination (Phelps, 1972). Being a manifestation of information-related frictions, this kind of bias might be expected to gradually disappear in consecutive years since, as more information is accumulated, the importance of the borrower's gender is attenuated. This potential statistical discrimination could be due to certain characteristics of male and female entrepreneurs, according to which the average creditworthiness of companies owned by women would be lower than that of their male counterparts. Such characteristics are not observable to econometricians but would be relevant when a decision is 
made about awarding a loan. Should this happen, we would observe a gender gap in credit granting, but no difference in terms of the quality of loans and the default rates, since the threshold applied to grant a credit would be the same for women as for men.

Because of this, in a third step, we track the performance of firm loans over time, finding that the probability of default is lower for loans granted to women in the company's foundation year and the subsequent year, and vanishes in the second and following years. Specifically, in the case of loans obtained in the first year, the probability of default is $14 \%$ lower for companies run by women, $12 \%$ lower in the case of credits obtained one year after the creation of company, and is not statistically different for subsequent years. This better credit performance of companies run by women, coincident with their lower probability of obtaining a credit (10\% in the first year, $8 \%$ one year later, and no difference in subsequent years), is not consistent with the explanation that the decision to grant credit is based on unobservable group characteristics or is economically rational (statistical discrimination). This is especially relevant since is a more clear evidence of credit quality than ex-ante proxy variables that are commonly used in the literature that, as Moro et al. (2017) assess, are limited to very basic controls.

By contrast, this evidence points to the existence of double standards that stem from less intentional and rational evaluation rules in the mind of the decision-maker that could result in implicit (unconscious) discrimination, as Bertrand et al. (2005) have proposed. The existence of double standards/implicit discrimination in the access to credit for start-ups is a major finding which reveals and quantifies a common belief in the credit market about gender related asymmetries, as many previous papers have sought to evidence. It also proves particularly pertinent given that in order to solve the double standard problem, unlike taste-based or statistical discrimination problems, the solution lies in increasing bank officer awareness of the possible presence of gender bias in the credit granting process as well as formulating explicit and objective criteria and standards to evaluate creditworthiness. In this sense, we think that by revealing such a problem our analysis takes a firm step towards reducing or even eliminating it.

To sum up, our paper makes four main contributions. First, the Spanish CIRBE database allows us to cover the whole population of credit demand and credit access in Spain, avoiding the inconveniences of subjective surveys, or multi-country samples where Spanish firms represent a limited picture of the Spanish credit market that might bias the outcome (e.g. Galli and Rossi, 2016 and Stefani and Vacca, 2013 use the ECB SAFE survey of small- and medium-size enterprises; Ongena and Popov, 2016 use the Business Environment and Enterprise Performance Survey (BEEPS) by the World Bank and the EBRD).

Second, the study is focused on new companies, which are especially interesting since they have no previous credit history, such that the credit score models applied to them by banks are different from those used for established firms. Thus, the ex-anteinformational effect is widely reduced and the decision to grant a loan is based more on managerial than firm characteristics. Among these, gender is one objective and non-modifiable measure. This allows us to reduce as much as possible the risk factors nonobservable to the econometrician but observable to the lender, as Alesina et al. (2013) pointed out. This is especially relevant, since previous literature on gender differences in credit demand typically uses already existing companies (Alesina et al., 2013; Aristei and Gallo, 2016; Bellucci et al., 2010; Galli and Rossi, 2016; Ongena and Popov, 2015; Treichel, 2006).

Third, the comprehensive and longitudinal nature of the database also allows us to carry out a dynamic empirical approach, looking at subsequent credit performance and tracking the credit performance of companies throughout the company life-cycle. This innovative strategy avoids some of the problems of omitted variables that plague previous studies, since instead of controlling for other variables that imperfectly capture the credit quality of the borrower we control for credit standard through credit performance. This allows us to assess borrower credit quality in a more straightforward manner than trying to approximate it by control variables such as, age, experience, education, personal delinquency, personal bankruptcy, legal judgments, or personal wealth, as is usually done in the literature (Blanchflower et al., 2003; Cavalluzzo and Wolken, 2005; Cole and Mehran, 2009; Coleman and Robb, 2009). This strategy is crucial vis-à-vis ruling out the hypothesis that lower (more) credit access for women (men) is due to lower (higher) quality of projects, since female-run companies behaved better than male ones in terms of credit performance (lower default rate).

Finally, and closely related to the previous point, this step by step analysis allows us not only to separate the demand from the supply side of the market, but also to disentangle different types of potential discrimination sources, discarding the presence of tastebased (dislike for female borrowers) and statistical discrimination (use of borrower's gender to proxy non-observable characteristics of credit worthiness) in favor of implicit discrimination (presence of double standards) as the only alternative to explain both the gender gap in credit granting and in credit performance. Thus, compared to other studies on gender differences in access to credit market that usually only explore Beckerian or/and statistical discrimination as possible causes of gender gaps (Alesina et al., 2013; Bellucci et al., 2010; Muravyev et al., 2009), we go a step further in an attempt to disentangle the three main types of discrimination usually posed by the literature.

\section{Theoretical framework on gender discrimination}

In credit markets, gender discrimination acts as a barrier against women's careers when female entrepreneurs seek funding to start a new un-established small enterprise. Access to financial resources is key to funding the required investments and to the subsequent profitability and growth of the company. Therefore, any barrier or obstacle in the credit market might prevent the business from opening and, even if the firm is ultimately set up, may have a lasting and negative impact on its survival and success.

Several theories have been proposed to explain differences in the way markets treat discriminated groups. Firstly, Becker (1957) proposed taste-based discrimination, in which the market participant is willing to sacrifice part of the profit in order to avoid contracting the disliked member of the discriminated group out of prejudice or bias. Taste-based discrimination is originated by preferences and cultural beliefs about gender that may influence lender decisions on loan applications. Taste-based discrimination would occur when those responsible for approving loans may inherently dislike female borrowers (prejudices) and prefer not to associate with them, even though it may be to their own detriment in terms of lost efficiency or reduced income to indulge such tastes. This would 
result in female borrowers being offered less credit, suffering higher denial rates, or facing higher interest rates under what are otherwise similar circumstances to male borrowers. Becker's theory predicts that such discriminatory practices tend to disappear with competition among lenders, as those who prefer not to finance women businesses are no longer able to bear the higher costs.

In the case of statistical discrimination (Phelps, 1972), since borrowers' demographic characteristics could be correlated with unobserved characteristics of credit, the lender can use borrower gender to proxy creditworthiness. This way, if female borrowers are on average more or less likely to default, then loan officers can apply to specific female-led firms the average quality of funded femaleled firms in an attempt to minimize the cost of gathering more directly relevant information about the borrower. According to Bellucci et al. (2010), this discrimination has its origin in the lower diffusion of female-owned businesses in the economy, which provides limited and less reliable information on these firms. This leads lenders to economize, inferring the likelihood of default on the loan, using the average information available on the creditworthiness of current female-owned firms. As a result of the adverse selection that stems from the difficulties creditworthy female borrowers face when accessing credit (individuals from the discriminated group are discouraged from participating in the credit market), the average quality of female firms decreases, perpetuating the difficulties in accessing credit for female borrowers in what becomes a vicious circle.

Another explanation of potential discrimination has been proposed by Bertrand et al. (2005). Underlying taste-based and statistical

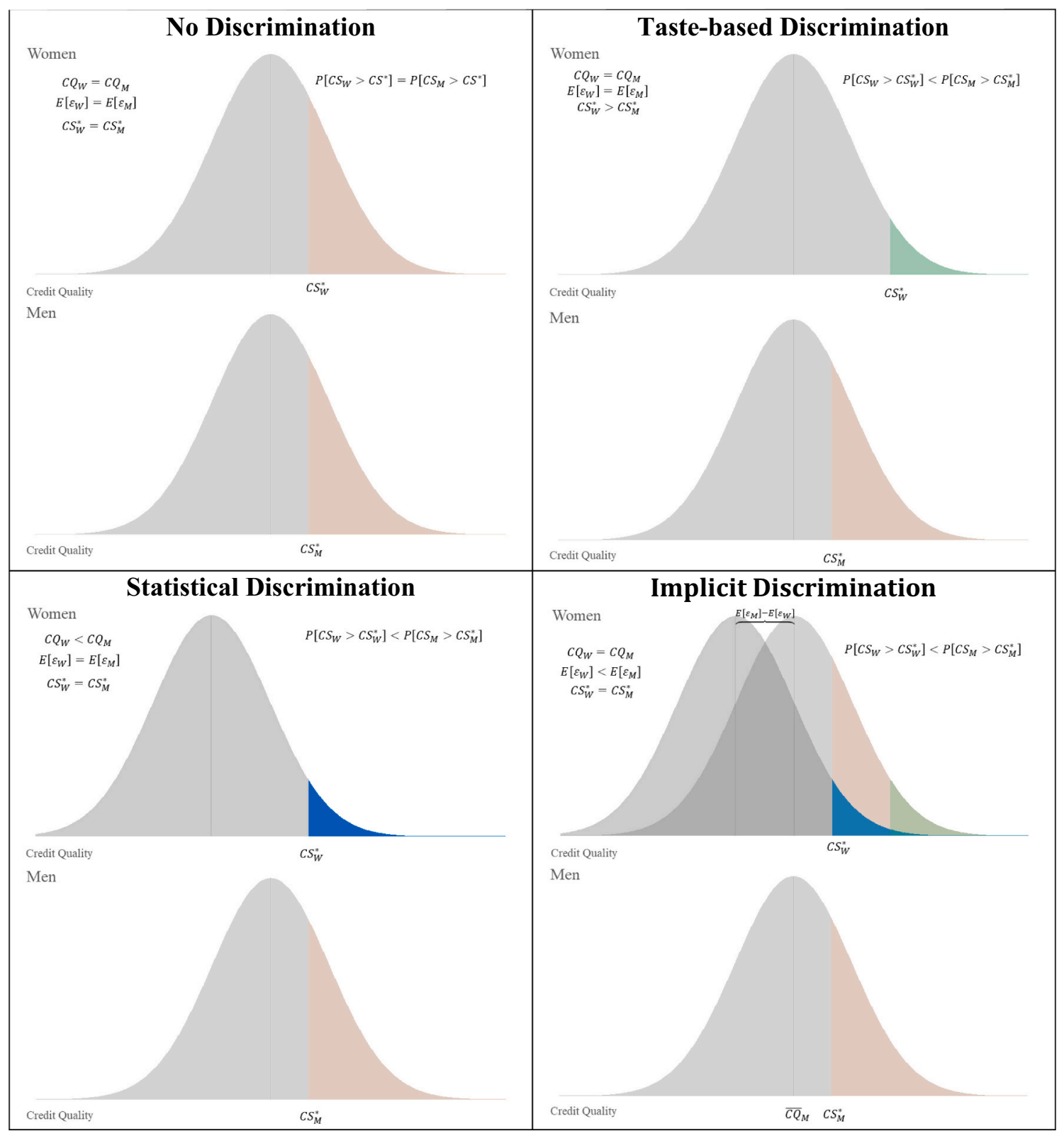

Fig. 1. Types of discrimination. 
discriminations is an awareness to discriminate, either for personal motivation or because belonging to a group provides relevant information. However, there may be a different motivation, which is less intentional and that involves greater unawareness, and which leads to discrimination. This kind of discrimination comes from a recent body of psychological evidence that distinguishes between explicit and implicit attitudes and how they influence human behavior. In this way, different experiments using the Implicit Association Test (IAT) show how implicit attitudes can influence behavior in meaningful ways, especially in contexts of inattentiveness, time pressure, and ambiguity. In this latter case, social psychologists argue that behavior may be more prone to implicit attitudes, and that implicit discrimination is more likely to occur in contexts where multiple, non-racist explanations for behavior might exist (Bertrand et al., 2005). In the context of the credit market, there might be an implicit attitude which favors granting loans to male entrepreneurs even though the contrary has been explicitly expressed. Thus, women would be less likely to obtain credit, not as a result of rational evaluations, but as a consequence of unintentional rules and credit scoring evaluations that would involve setting the bar higher when evaluating women's businesses as compared to men's, and which are not based on economic grounds and lie outside discriminator awareness. This implicit discrimination would be more likely in time pressure contexts, if assessment involves considerable ambiguity (granting a loan to a firm starting up is not clear, nor is there a simple formula), and if information is insufficient (for instance, if there are no records about the lender's previous activity).

In this context, our work aims to identify whether there is less credit access for female entrepreneurs, and specifically whether this is due to possible economic discrimination, or the result of lower credit quality of entrepreneurs and their companies. In order to do this, we must isolate the companies that are in fact requesting a loan, thus eliminating demand side factors. This can be done by restricting the sample to companies which we know have applied for a loan (as in Jiménez et al., 2012, 2014, 2017) and therefore see, conditional on that explicit credit demand, whether or not they were able to secure a loan.

Once we have the subsample of companies that have currently applied for a loan, we look for evidence of gender bias, testing whether the probability of female entrepreneurs being granted a bank loan is lower than for male entrepreneurs. Should evidence of such a gender gap in credit access exist, we will try to disentangle the type of discrimination that may be behind it.

Let us assume that $C Q_{i}$ is an unobservable random variable which represents the credit quality of entrepreneur $i$. When an entrepreneur approaches a financial institution/bank, this bank must assess the credit quality of the project by the credit scoring $\left(C S_{i}\right)$, which can be considered an approximation to the real value of $C Q_{i} C Q_{i}\left(C S_{i}=C Q_{i}+\varepsilon_{i} C S_{i}=C Q_{i}+\varepsilon_{i}\right)$. Therefore, the bank will grant the loan if the estimated credit scoring is above a given credit standard $\left(C S_{i}^{*}\right)$. Thus, the probability of obtaining a loan $\left(\mathrm{P}\left[C S_{i}>C S_{i}^{*}\right]=\mathrm{P}\right.$ $\left.\left[C Q_{i}+\varepsilon_{i}>C S_{i}^{*}\right] P\left[C S_{i}>C S_{i}^{*}\right]=P\left[C Q_{i}+\varepsilon_{i}>C S_{i}^{*}\right]\right)$ will depend on both credit quality and observation error. In the event of no discrimination, where the credit quality, credit standard, and observation errors are equal for female and male entrepreneurs, the probabilities of obtaining a loan should be the same (Fig. 1, top-left).

Starting with the more explicit and intentional form of discrimination, i.e., taste-based discrimination, this would imply that the lender's distaste towards female borrowers would incline them to behave negatively, by imposing higher credit standards on women $\left(C S^{*}{ }_{W}>C S^{*}{ }_{M}\right)$ to access formal bank credit as compared to male counterparts (Fig. 1, top-right). Moreover, given that Beckerian discrimination stems from preferences and cultural beliefs about gender that are pervasive and persistent, we might expect that adding new available information about the female-owned business would not change the lender's perceptions. We would thus expect that the lower probabilities of granting credit for female entrepreneurs would not disappear in the years following the company's foundation. If, on the other hand, we observe that these barriers disappear in subsequent years, we could exclude this kind of discrimination.

In the latter case, where discrimination disappears over time, we should consider subtler and more unconscious types of gender bias. This way, if our results were consistent with statistical discrimination and if the decision to grant a loan to companies run by women were correlated with some unobservable characteristics, the bank officer would judge the female applicant on the basis of her group averages rather than solely on the basis of her own business creditworthiness. Thus, the bank officer would use the lower credit quality distributions of female-owned firms $\left(C Q_{W}<C Q_{M} C Q_{W}<C Q_{M}\right)$, since the information about them is limited compared to that of men (e.g., due to differences in business background, motivation or less management experience) to apply the same credit standards to both women and men, which would result in a lower likelihood of credit for women than for men. However, a second consequence would be that, since credit standards are the same for male and female entrepreneurs, the default rate of female run companies would be similar to that of male run companies. This would show that the decision, although discriminatory, was rational from an economic point of view (Fig. 1, bottom-left).

Finally, the more subtle and automatic type of discrimination -implicit discrimination - would lead credit officers to unconsciously underestimate $\left(E\left[\varepsilon_{W}\right]<E\left[\varepsilon_{M}\right]\right)$ the credit quality of new women-led companies when considering the entrepreneur's credit scoring. This implicit bias of the credit quality of women's startups would, at the same time, lead us to observe a lower percentage of loans granted to new businesses owned by women, and a lower default ratio among new women-led businesses that were granted loans compared to their male counterparts. Although these two facts may seem counterintuitive, since fewer women-led firms comply with bank loan requirements, one would expect no differences in performance compared to their male counterparts. They may, as argued in the case of statistical discrimination, occur simultaneously in the presence of implicit discrimination. This way, although bank officers consciously believe they are applying the same standards to both men and women-led companies, since implicit discrimination leads them to unconsciously underestimate the credit quality of their business, they would be implicitly setting higher bars to evaluate women-led businesses as compared to men-led businesses. This results in a double standard that gives rise to lower default ratios among women's start-ups who faced greater difficulties when seeking to secure a loan (Fig. 1, bottom-right).

\section{Data}

Our empirical analysis matches two separate databases. Sabi is a comprehensive database that includes official register information 
for almost all Spanish companies. Through Sabi, we first identify companies created in Spain between 2004 and 2014 , and to select those with a solo entrepreneur and at least one employee in the first year of the company's life (Table 1). The former condition allows us to identify the "gender of a company"; the latter excludes companies with no real activity (i.e., many companies are created to protect real estate assets for fiscal purposes). Both conditions produce a database of 84,586 companies, with 17,726 of them run by a female entrepreneur (21\%) (see Fig. 2). As $91 \%$ of the Spanish companies in the database have either multiple directorships or no economic activity, our sample is $9 \%$ of the population. As shown in Figs. 3 and 4, there are differences across regions and industries in terms of male or female leadership of these companies.

As a second step, we merge this sample with the Spanish Credit Register run by the Spanish Central Bank (CIRBE). CIRBE is a comprehensive and confidential database of all banks and credit institutions operating in Spain. These institutions must file monthly reports of all outstanding loans (with an outstanding amount of at least 6000€) owed by Spanish individuals and corporations, as well as their performing situation (normal, doubtful, in arrears, and write-off). The high level of banking sector penetration in the Spanish economy and the very low level of the $6000 €$ hurdle implies that the database covers an extremely high proportion of Spanish lending activity. The second key point of this database is that when a bank or credit institution is assessing fresh credit for a company or individual, it sends an information request to CIRBE (with the written consent of the firm or individual) concerning the credit situation of the individual/firm. CIRBE keeps records of all these information requests, which can be identified as loan applications from an individual/firm (e.g., Jiménez et al., 2012, 2014, 2017). ${ }^{1}$ Fig. 5 tracks all 84,586 companies' demand for credit since their founding. The demand for credit ranges between $30 \%$ and $50 \%$ for the year the companies are created, and steadily decreases to around $15-20 \%$ once companies get older. As depicted, companies' demand for loans diminishes with time, since other financing sources become available.

Once we identify credit demand, we match loan applications to actual loans. In order to do so, we track the firm's outstanding loans (according to CIRBE) in the month the credit was requested and the following three months. We consider a loan is approved when the bank has increased the outstanding loans to that firm. We consider a loan is rejected when we do not observe that increase. ${ }^{2}$ This identification procedure is the same as used by Jiménez et al. (2012, 2014, 2017). Fig. 6 shows the proportion of firms that, having asked for a loan, are given one. As can be seen, the proportion of credit access depends to a great extent on the economic situation, with a proportion of credit access in the year of the firm's creation of around 75-80\% pre crisis, to below 55\% in 2012-2013. There is a reduction in the likelihood of obtaining a loan once the company gets older, but there are also differences depending on the credit cycle.

Due to large differences in credit access and credit demand depending both on the company's life cycle and the economic cycle, all analyses are performed separately for each year of the company life cycle, and we add year fixed effects to account for the economic cycle.

The final step of our analysis requires tracking the credit performance of the loans granted to those companies. Using the CIRBE database, we follow each loan for the available horizon, identifying whether the loan has been considered doubtful, has gone into arrears, or if the bank has given up trying to recover the loan and has written it off at any moment after having awarded the credit. Fig. 7 depicts the default ratios.

\section{Analysis}

\subsection{Credit demand}

First, we explore differences in credit demand between female and male entrepreneurs. In order to do so, we estimate a logit model (Eq. (1)) where the dependent variable is a dummy variable that is equal to 1 if the company asked for a loan in a given year, and 0 otherwise. The independent variable is gender (female). Control variables are time (year), firm industry (2-digit industry level), region (50 provinces and two regions) and firm size (the equity of the firm at the beginning of the year).

$$
P\left(\text { Demand }_{i y}=1\right)=f\left(\beta_{y} \cdot \text { Female }_{i}+\gamma_{y} \cdot \text { InEquity }_{i y}+\delta_{\text {year }}+\vartheta_{\text {Industry }}+\vartheta_{\text {Province }}+\nu_{i y}\right)
$$

As shown in the estimation of Eq. (1) in Table 2, companies run by a female entrepreneur are about $10 \%$ less likely to request a loan than a firm run by a male in the year the company is created (Table 3, column 1). It is worth noting that this gender gap in credit demand remains even years after the company's creation (Columns 2-11 in Table 3), where women-led companies are between 10\% and $25 \%$ less likely to ask for a bank loan. This result confirms the hypothesis that female entrepreneurs are less likely request a loan. There are several possible explanations for this outcome. The most obvious explanation is to consider that women are more risk averse than men (Jianakoplos and Bernasek, 1998; Sunden and Brian, 1998), and so are less likely to look for a more leveraged company. However, an alternative explanation, in line with Schubert et al. (1999) and Ongena and Popov (2016), is that women would not ask for a loan because they anticipate (correctly or incorrectly) that they are less likely to be given it. We will explore this in the following section.

\footnotetext{
${ }^{1}$ Although data protection laws do not allow us to study individuals, these laws do not affect firms, which are the subject of this study.

${ }^{2}$ To construct this variable, we will look at the debt increase of this company with that bank between the month previous to the consultation and the three months after consultation. If there is an increase in the sum of loans and stand-by credit in any of those months, we consider the loan to have been approved (approval $=1$ ) while if there is no such increase, we deem the request to have been rejected $($ approval $=0$ ).
} 
Table 1

Descriptive statistics.

\begin{tabular}{|c|c|c|c|c|}
\hline Year & Female & Credit demand & Credit access & Number of obs. \\
\hline 2004 & $19.6 \%$ & $31.1 \%$ & $75.7 \%$ & 9476 \\
\hline 2005 & $18.6 \%$ & $29.4 \%$ & $76.7 \%$ & 8850 \\
\hline 2006 & $18.8 \%$ & $40.7 \%$ & $78.6 \%$ & 9997 \\
\hline 2007 & $18.4 \%$ & $46.9 \%$ & $77.9 \%$ & 7073 \\
\hline 2008 & $20.0 \%$ & $40.5 \%$ & $70.0 \%$ & 7080 \\
\hline 2009 & $22.2 \%$ & $42.8 \%$ & $62.5 \%$ & 6750 \\
\hline 2010 & $23.4 \%$ & $42.5 \%$ & $63.5 \%$ & 6990 \\
\hline 2011 & $23.1 \%$ & $45.6 \%$ & $61.9 \%$ & 4150 \\
\hline 2012 & $22.5 \%$ & $34.0 \%$ & $54.2 \%$ & 8155 \\
\hline 2013 & $23.1 \%$ & $36.9 \%$ & $53.2 \%$ & 9366 \\
\hline 2014 & $22.9 \%$ & $44.5 \%$ & $62.0 \%$ & 6699 \\
\hline
\end{tabular}

12000

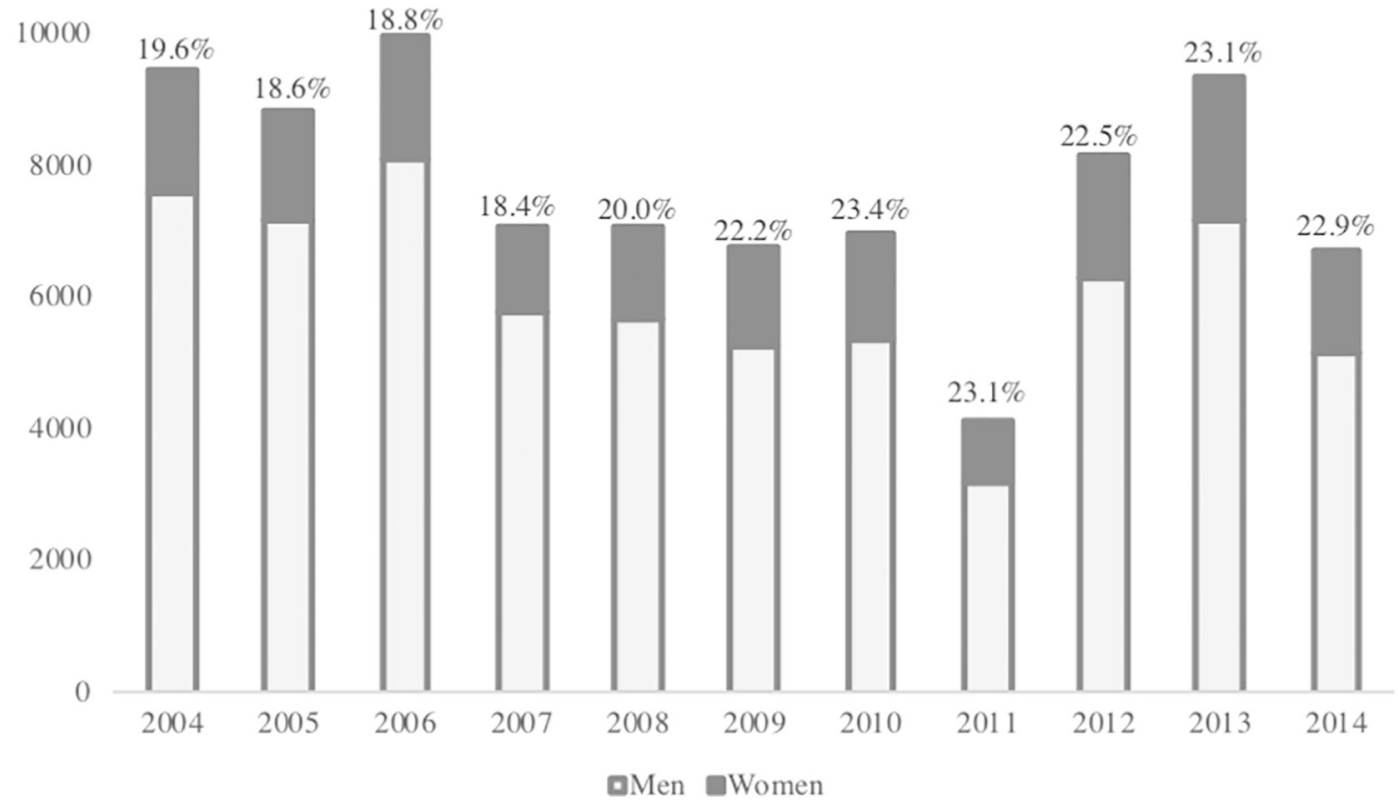

Fig. 2. Number of companies and proportion of them led by a woman, by year of creation.

\subsection{Credit access}

Once we isolate the firms that indeed asked for a bank loan in a given year, we then look at whether those companies were successful in obtaining a loan. Thus, we restrict our analysis to the subsample of firms that have asked for a loan in the previous step of the analysis in order to isolate the supply from the demand side, and again use a logit model, in this case with the dependent variable a dummy variable that is equal to 1 if the firm has secured a loan, and 0 otherwise. As we did in the previous model, we separate the analysis depending on the age of the firm, using a different logit regression for each year since firm's creation. Thus, as happens with logit models on the credit demand, this is equivalent to estimating a single model with fixed effects not only on the year, industry and region (province), but also on the firm age, as well as interactions of the latter with all the other variables and fixed effects.

In the first year of a company's existence, there are no records on its profitability, so banks and credit institutions judge potential credit performance based on entrepreneur characteristics (of which gender is one of the most evident), the collateral the firm can provide (García-Posada and Mora-Sanguinetti, 2014), type of business, and local market where the loan is requested. To control for collateral, we include the firm's equity that considers the entrepreneur's initial capital (Table 3). Business and market conditions are accounted for by industry and regional dummy variables.

$$
P\left(\text { Credit_Access }_{i y}=1 / \text { Demand }_{i y}=1\right)=f\left(\beta_{y} \cdot \text { Female }_{i}+\gamma_{y} \cdot \text { InEquity }_{\text {iy }}+\delta_{\text {year }}+\vartheta_{\text {Industry }}+\vartheta_{\text {Province }}+\nu_{\text {iy }}\right)
$$

Table 4 depicts results from estimating Eq. (2). As shown, among newly founded companies, a female entrepreneur reduces the 


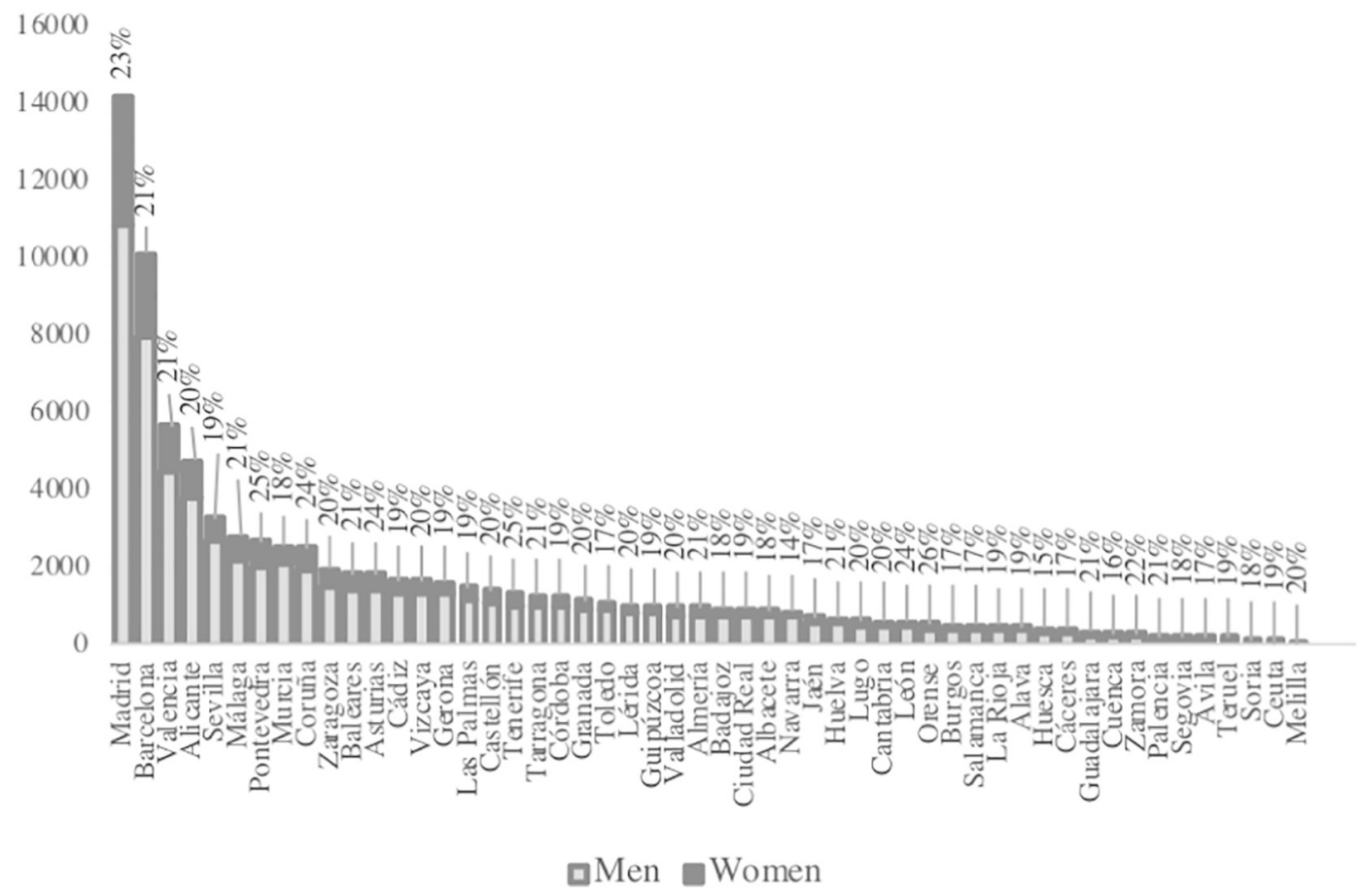

Fig. 3. Number of companies and proportion of them led by a woman, by province.

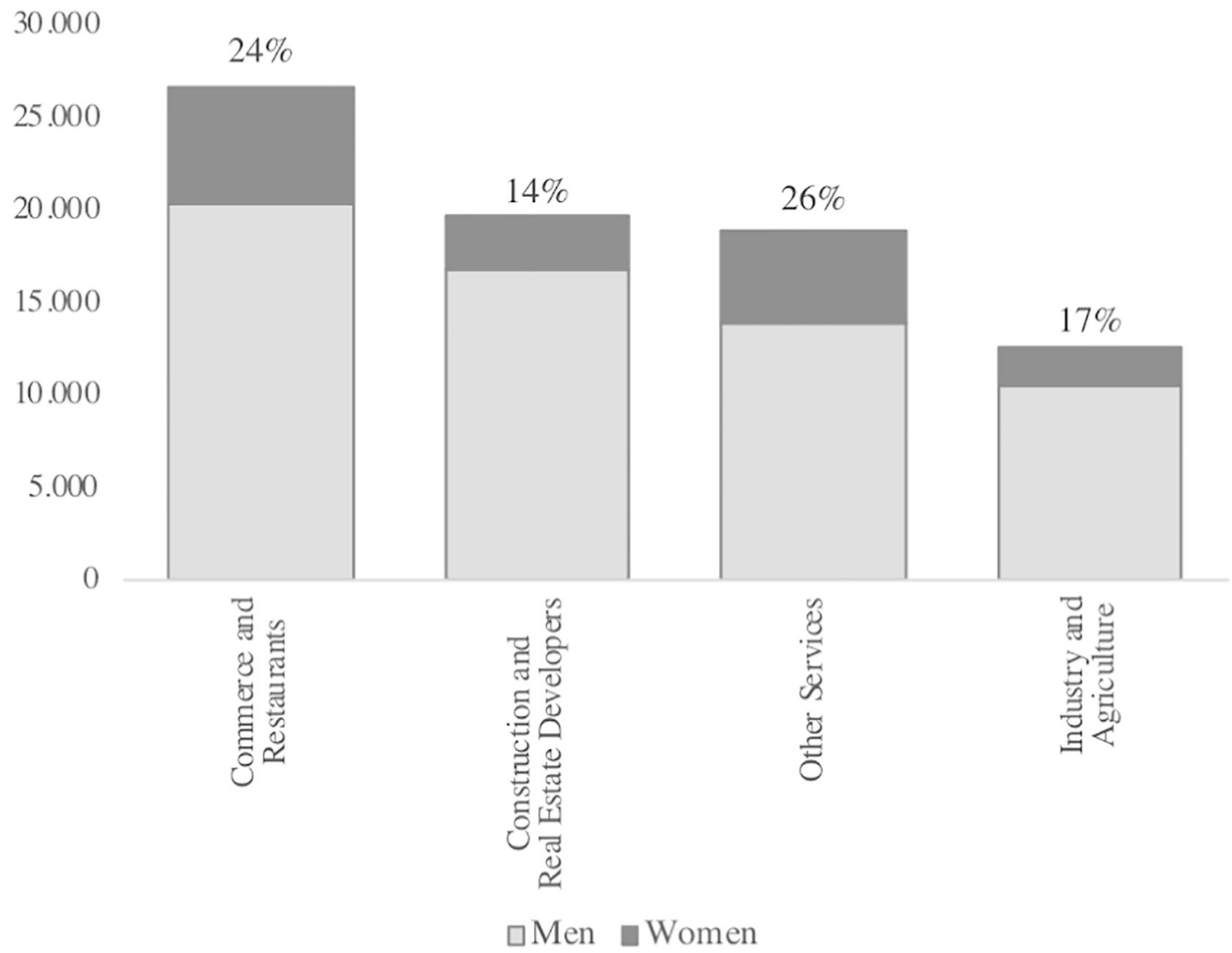

Fig. 4. Number of companies and proportion of them led by a woman, by industry. 


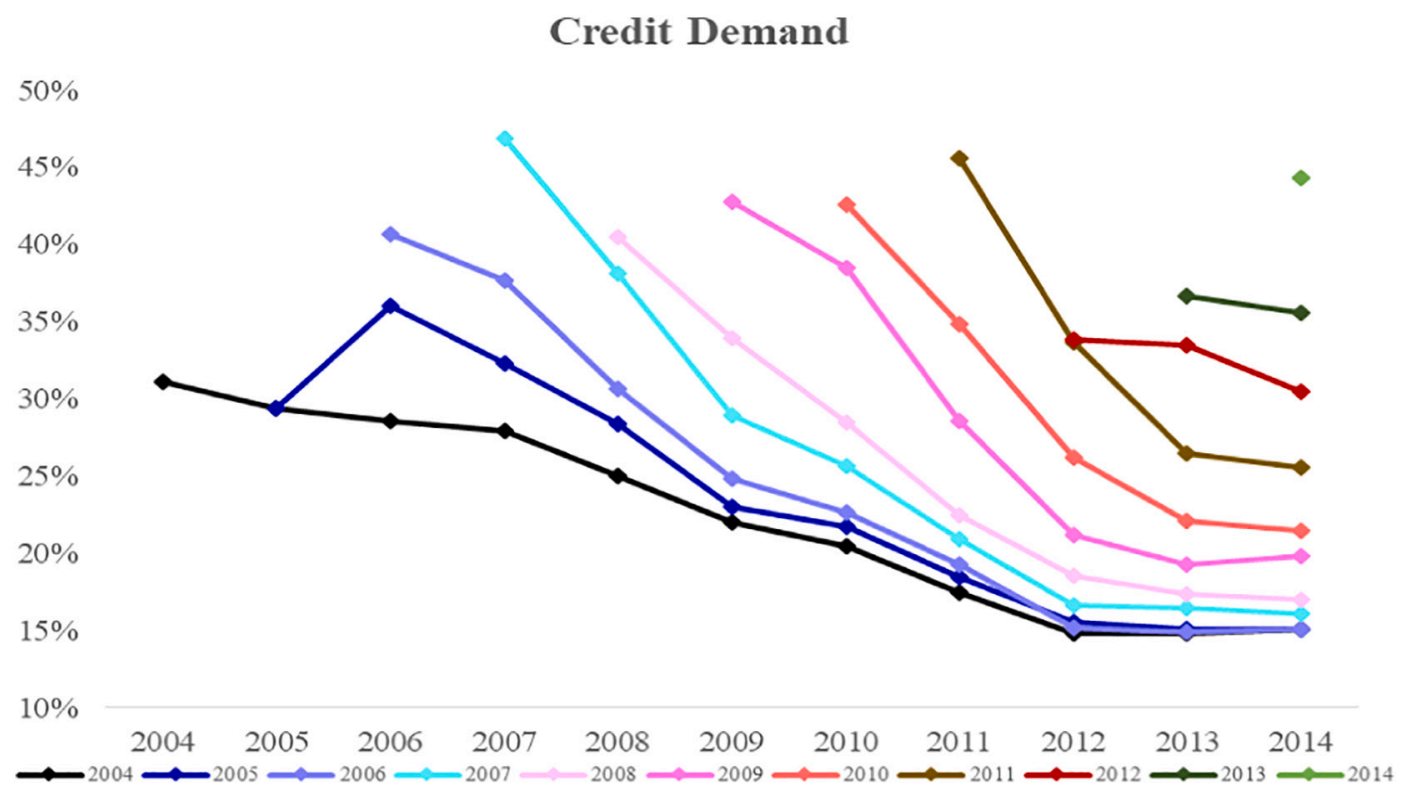

Fig. 5. Number of companies requesting a loan, by year of creation.

\section{Credit Access}

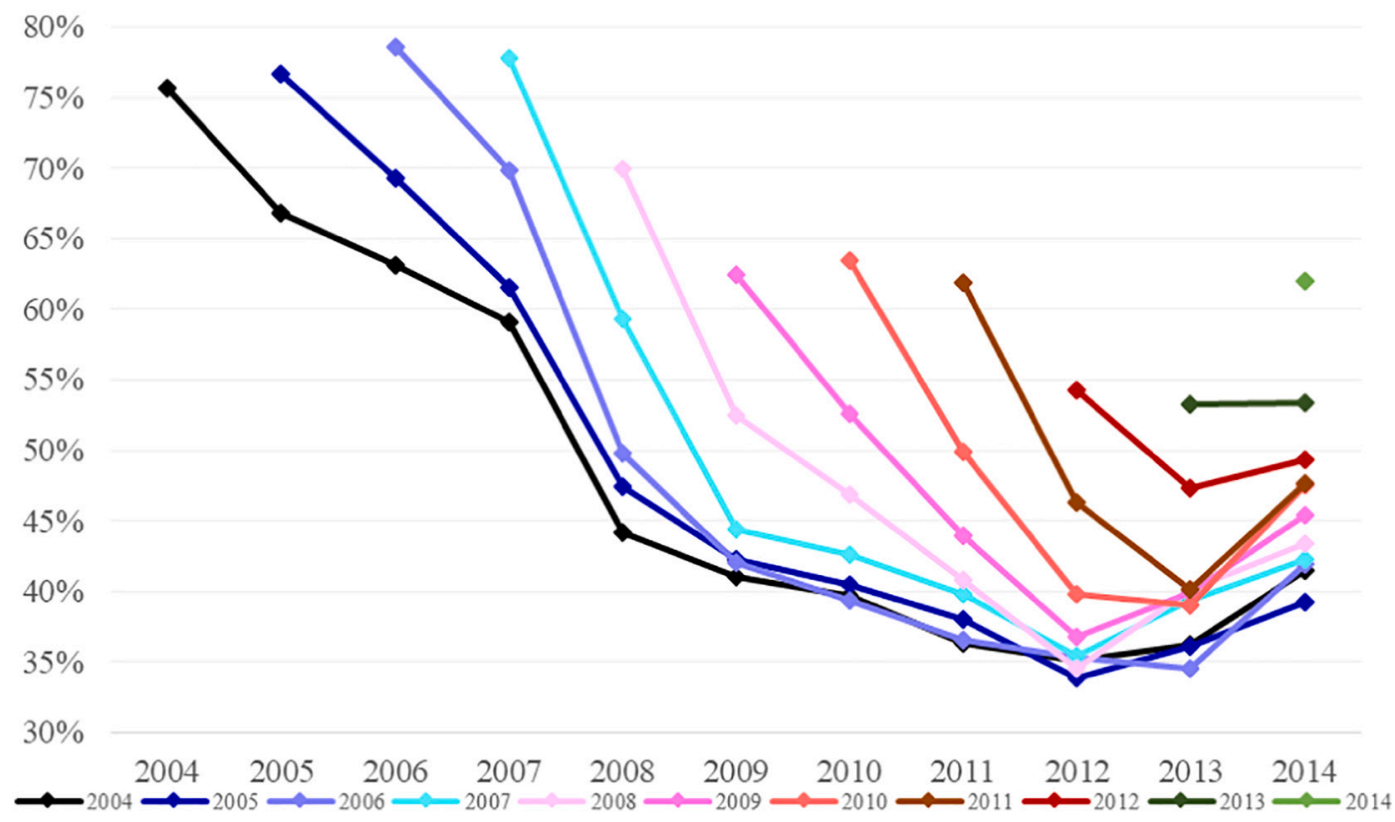

Fig. 6. Proportion of firms obtaining a loan, by year of creation.

odds of receiving a loan by roughly $10 \%$. One plausible cause is that given the lack of perfect information to analyze the characteristics of the individual entrepreneur asking for the loan, gender can be used to proxy unobservable specific and differential group characteristics (statistical discrimination). Nevertheless, as the company gets older and there is more information available on firm performance (Profit \& Loss accounts), banks and credit institutions no longer need to check on difficult to gather individual information. Characteristics such as gender no longer prove to be a relevant factor. As can be seen in Table 4, in the year the company is created (column 1), women entrepreneurs are less likely to secure a loan than their male counterparts. This continues the year after the company's creation (column 2), although the effect is only marginally significant. It then subsequently dissipates (columns 3 to 11 ).

These results clearly rule out the existence of taste-based discrimination in the credit industry given that, in the second year, differences in credit access between men and women companies disappear and remain insignificant the following years. This might 


\section{Credit Default}

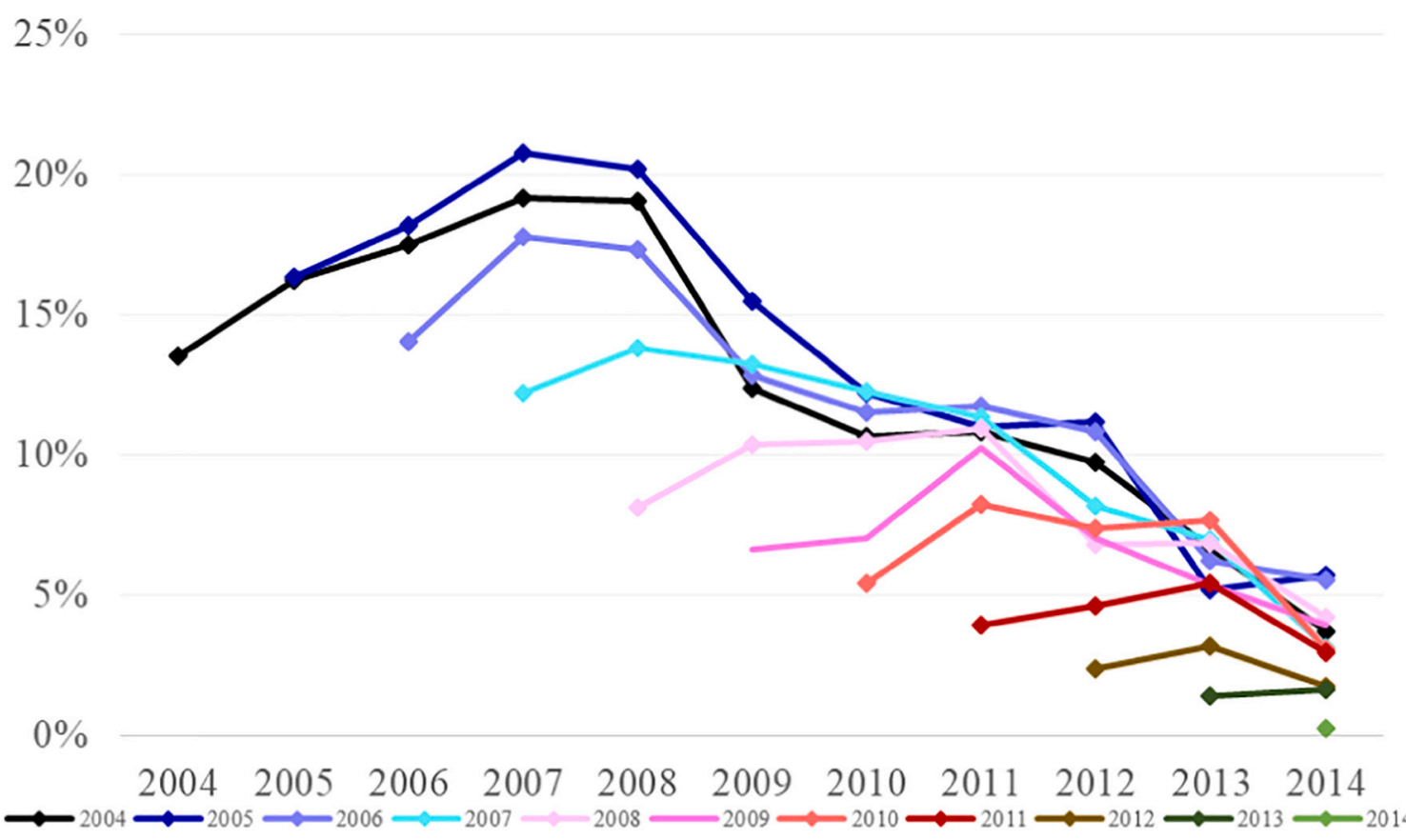

Fig. 7. Proportion of credit default, by year of company creation.

come from the lack of information on a specific person, which leads to the average group quality being applied. This might be lower for female-owned firms, due to them being less experienced or committed to the company, or even because they are less inclined towards risk taking. None of these characteristics are observable to us, but would imply that credit demand was of a lower quality. It would then be economically justifiable to reduce credit supply to these groups (statistical discrimination). However, the lower probability of women-led companies obtaining a loan might not be based on rational evaluations, but due to unintentional rules and credit scoring evaluations. This would imply that higher bars have been set to evaluate female-run businesses compared to male-run businesses (double standards) and that decisions are not based on economic foundations and lie outside discriminator awareness (implicit discrimination). This is the key point of the following estimations.

\subsection{Credit performance}

We now try to disentangle which type of discrimination (statistical or implicit double standards) might lie behind the lower likelihood of women entrepreneurs getting a loan by looking at the future performance of those loans. In the case of statistical discrimination, the decision to award credit would be rational, and based on the differential average characteristics of male and female entrepreneurs. Thus, future credit performance would be independent of borrower gender, since the credit rating would merely have been taking proper account of such characteristics. However, if implicit double standards are prevalent, the decision to discriminate a group would not be based on rational reasoning vis-à-vis the credit quality of the company, and would thus be creating an unconscious double standard that penalizes women. In this latter situation, the higher implicit standards required for women will lead to their credit performing better. We therefore specify a logit model on credit performance for the subsample of companies who obtained a loan (Eq. (3)). The dependent variable will be equal to one if we observe that, in the future, the bank classifies the credit obtained in a given year of the life's company either as doubtful, in arrears or written-off, and equal to zero if it has never been in that position. Independent variables are entrepreneur gender, original leverage ratio, and fixed effects by year, industry and province.

$$
P\left(\text { Non_Performing }_{i y}=1 / \text { Credit_Access }_{i y}=1\right)=f\left(\beta_{y} \cdot \text { Female }_{i}+\gamma_{y} \cdot \text { Debt } / \text { Equity }_{i y}+\delta_{\text {year }}+\vartheta_{\text {Industry }}+\vartheta_{\text {Province }}+\nu_{\text {iy }}\right)
$$

Eq. (3) estimations are shown in Table 5, where each column represents the estimation of loan performance for the credit obtained in each year since company's creation. In the case of the credits obtained in the founding year, we observe that the probability of the credit going into default is $14 \%$ less likely in the case of loans given to women-led companies. Had the level of credit worthiness used for women and men been the same, we would not expect such an outcome. However, since women-led companies show better credit performance, it implies that the credit quality was higher than men-led companies who also obtained a loan in the year the firm was founded. Moreover, these women-owned companies with better credit performance are the same ones who had a tougher time obtaining credit in their foundation year (indeed, they were $10 \%$ less likely to obtain a credit when requesting it). This would be 
Table 2

Logit regression on the probability of a firm seeking a loan in a given year after the creation of the firm.

\begin{tabular}{|c|c|c|c|c|c|c|c|c|c|c|c|}
\hline & (1) & (2) & (3) & (4) & (5) & (6) & (7) & (8) & (9) & (10) & (11) \\
\hline & $\begin{array}{l}\text { Credit Demand } \\
\text { Year } 0\end{array}$ & $\begin{array}{l}\text { Credit } \\
\text { Demand Year } \\
1\end{array}$ & $\begin{array}{l}\text { Credit } \\
\text { Demand Year } \\
2\end{array}$ & $\begin{array}{l}\text { Credit } \\
\text { Demand Year } \\
3\end{array}$ & $\begin{array}{l}\text { Credit } \\
\text { Demand Year } \\
4\end{array}$ & $\begin{array}{l}\text { Credit } \\
\text { Demand Year } \\
5\end{array}$ & $\begin{array}{l}\text { Credit } \\
\text { Demand Year } \\
6\end{array}$ & $\begin{array}{l}\text { Credit } \\
\text { Demand Year } \\
7\end{array}$ & $\begin{array}{l}\text { Credit } \\
\text { Demand Year } \\
8\end{array}$ & $\begin{array}{l}\text { Credit } \\
\text { Demand Year } \\
9\end{array}$ & $\begin{array}{l}\text { Credit } \\
\text { Demand Year } \\
10\end{array}$ \\
\hline Female CEO & $\begin{array}{l}-0.099^{* * * * * *} \\
(0.018)\end{array}$ & $\begin{array}{l}-0.090^{* * *} \\
(0.023)\end{array}$ & $\begin{array}{l}-0.159^{* * *} \\
(0.028)\end{array}$ & $\begin{array}{l}-0.184^{* * *} \\
(0.033)\end{array}$ & $\begin{array}{l}-0.192^{* * *} \\
(0.036)\end{array}$ & $\begin{array}{l}-0.190^{* * *} \\
(0.040)\end{array}$ & $\begin{array}{l}-0.243^{* * *} \\
(0.045)\end{array}$ & $\begin{array}{l}-0.288^{* * *} \\
(0.052)\end{array}$ & $\begin{array}{l}-0.230^{* * *} \\
(0.061)\end{array}$ & $\begin{array}{l}-0.132^{* * *} \\
(0.076)\end{array}$ & $\begin{array}{l}-0.199^{*} \\
(0.107)\end{array}$ \\
\hline Equity & $\begin{array}{l}0.084^{* * *} \\
(0.005)\end{array}$ & $\begin{array}{l}0.064^{* * *} \\
(0.006)\end{array}$ & $\begin{array}{l}0.082^{* * *} \\
(0.006)\end{array}$ & $\begin{array}{l}0.122^{* \ldots *} \\
(0.007)\end{array}$ & $\begin{array}{l}0.142^{* * *} \\
(0.008)\end{array}$ & $\begin{array}{l}0.139^{* * *} \\
(0.009)\end{array}$ & $\begin{array}{l}0.166^{* * * *} \\
(0.010)\end{array}$ & $\begin{array}{l}0.192^{* * * *} \\
(0.012)\end{array}$ & $\begin{array}{l}0.174^{* * *} \\
(0.013)\end{array}$ & $\begin{array}{l}0.183^{* * *} \\
(0.017)\end{array}$ & $\begin{array}{l}0.152^{* * *} \\
(0.023)\end{array}$ \\
\hline Year FE & Yes & Yes & Yes & Yes & Yes & Yes & Yes & Yes & Yes & Yes & Yes \\
\hline Industry FE & Yes & Yes & Yes & Yes & Yes & Yes & Yes & Yes & Yes & Yes & Yes \\
\hline Province FE & Yes & Yes & Yes & Yes & Yes & Yes & Yes & Yes & Yes & Yes & Yes \\
\hline \# observations & 81,640 & 56,234 & 42,354 & 33,456 & 28,841 & 24,292 & 19,999 & 15,685 & 11,833 & 7468 & 3757 \\
\hline Pseudo R2 & 0.0290 & 0.0224 & 0.019 & 0.0236 & 0.0287 & 0.0302 & 0.0376 & 0.0417 & 0.0423 & 0.0536 & 0.0536 \\
\hline LR stat & $3162^{* \ldots *}$ & $1654^{* * * *}$ & $1006^{* * * *}$ & $967.4^{* * *}$ & $992.4^{* * *}$ & $861.0^{* \cdots *}$ & $861.5^{* \cdots *}$ & $738.4^{* \cdots *}$ & $560.3^{\text {***k }}$ & $443.6^{* * *}$ & $232.4^{* * *}$ \\
\hline $\begin{array}{c}\text { Odds ratio } \\
\text { Female } \\
\text { CEO }\end{array}$ & 0.906 & 0.914 & 0.853 & 0.832 & 0.825 & 0.827 & 0.784 & 0.750 & 0.795 & 0.877 & 0.819 \\
\hline
\end{tabular}

Standard errors in parentheses. The dependent variable is a dummy variable if the company has asked for a bank loan. Each column represents the years to have elapsed since the creation of the firm (from year 0 to year 10). We control by firm industry ( 2 digits CNAE), year, province and firm size (the log of the equity). Sample range from companies created in 2004 to those created in 2014.

$p<0.01$

**: $p<0.05$

$p<0.10$. 
Table 3

Initial equity of firms in the year of their creation.

\begin{tabular}{|c|c|c|c|c|c|c|c|c|c|}
\hline & \multicolumn{3}{|c|}{ Log (equity) } & \multicolumn{3}{|c|}{ Log (equity) - Male } & \multicolumn{3}{|c|}{ Log (equity) - Female } \\
\hline & \#obs. & Mean & Std.Dev. & \#obs. & Mean & Std.Dev. & \#obs. & Mean & Std.Dev. \\
\hline 2004 & 9320 & 1.933 & 1.419 & 7489 & 1.954 & 1.413 & 1831 & 1.848 & 1.440 \\
\hline 2005 & 8667 & 2.012 & 1.507 & 7055 & 2.014 & 1.482 & 1612 & 2.004 & 1.613 \\
\hline 2006 & 9776 & 1.972 & 1.493 & 7938 & 1.978 & 1.480 & 1838 & 1.950 & 1.551 \\
\hline 2007 & 6955 & 2.025 & 1.511 & 5677 & 2.052 & 1.513 & 1278 & 1.909 & 1.495 \\
\hline 2008 & 6989 & 1.962 & 1.483 & 5599 & 1.995 & 1.498 & 1390 & 1.829 & 1.413 \\
\hline 2009 & 6680 & 1.896 & 1.389 & 5195 & 1.936 & 1.416 & 1485 & 1.756 & 1.227 \\
\hline 2010 & 6948 & 1902 & 1394 & 5321 & 1.959 & 1.436 & 1627 & 1.713 & 1.227 \\
\hline 2011 & 4128 & 2.062 & 1.512 & 3173 & 2.101 & 1.545 & 955 & 1.933 & 1.392 \\
\hline 2012 & 8164 & 1.907 & 1.456 & 6294 & 1.942 & 1.488 & 1817 & 1.797 & 1.348 \\
\hline 2013 & 9364 & 1.908 & 1.441 & 7167 & 1938 & 1.451 & 2149 & 1.814 & 1.411 \\
\hline 2014 & 6696 & 1.965 & 1.490 & 5139 & 2006 & 1.536 & 1533 & 1.835 & 1.327 \\
\hline
\end{tabular}

tantamount to saying there were double standards for companies seeking loans depending on the gender of the director, with it being tougher for women-run companies. This is consistent with implicit discrimination, but not with statistical discrimination, since, in the latter case, we should not observe any difference in credit performance.

For subsequent years, the results are parallel to those observed in credit demand. In the case of loans obtained one year after company's creation, ventures run by women are $12.4 \%$ less likely (marginally significant) to go into default (they were $6.3 \%$ less likely to obtain a loan, also a marginally significant difference). However, for subsequent years, the likelihood of going into default is not statistically significant between firms run by women or men, in line with what happened at the moment the loan was granted.

\section{Robustness exercises}

In order to confirm the validity of our results, we have run several robustness exercises. All of them are in line with previous analyses.

\subsection{Construction vs. commerce}

The main driver of our results is that in the first year of a firm, the lack of hard data force banks to assess company credit worthiness using qualitative judgments, while in the following years, credit scoring can be derived from models fed by Profit \& Loss and Balance Sheet variables.

To further reinforce this intuition, we extracted two subsamples for industrial groups, one of which is construction and real estate developers. In this case, although banks lack information on the companies, they can rely on third party appraisals of the projects that are then used as collateral for the projects. The other subgroup is commerce and restaurants. These companies generally rent their locations and lack collateral, such that banks are not able to use quantitative models for their projects, and qualitative analysis remains the most relevant factor. The results of the previous analysis on both sectors are shown in Table 6 .

In the case of Construction and Real Estate Developers, we do not observe any difference between firms run by female and male directors, even for the first year of the company. By contrast, for Commerce and Restaurants, the effect for the first years is even clearer than for the whole sample, with lower credit access and higher credit performance for female-run companies. This result reinforces the idea that qualitative credit assessment is the root of implicit discrimination.

\subsection{Alternative performance measures}

We also use alternative measures of performance as an additional robustness exercise. In section 4.3, we use whether the company has gone into default in the following years, without limits. It might be argued that the longer the period used to assess performance, the more additional effects might appear influencing this measure. As an initial robustness, we have changed the definition of nonperforming to check only for the creditworthiness in the following two years after securing the loan. We use this lag because it is when there is a peak in the new defaults after loans are granted. Results are shown in Table 7.

Another way to look at performance is through quantitative loss in the event of loan default. We use a Tobit model (Tobin, 1958), as in Eq. (4), where the dependent variable is the amount of the loan that has defaulted. This variable is obviously censored (Loss $=0$ ) for cases in which no default has occurred. The estimation results for these regressions are shown in Table 8.

Loss $_{i y}=0$ if Default $_{\text {iy }}=0$.

$$
\text { Loss }_{i y}=\beta_{y} \cdot \text { Female }_{i}+\gamma_{y} \cdot \text { Debt } / \text { Equity }_{i y}+\delta_{\text {year }}+\vartheta_{\text {Industry }}+\vartheta_{\text {Province }}+\nu_{\text {iy }}
$$

We also estimate a Cox hazard model (Cox, 1972) for the likelihood of going into default at a given moment. This duration model where the variable explained is the time to default gives a hazard function for a given time and variables as shown in Eq. (5). The estimated parameters are shown in Table 9. 
Table 4

Logit model on the probability of getting a loan when requested.

\begin{tabular}{|c|c|c|c|c|c|c|c|c|c|c|c|}
\hline & (1) & (2) & (3) & (4) & (5) & (6) & (7) & (8) & (9) & (10) & (11) \\
\hline & $\begin{array}{l}\text { Credit Access } \\
\text { Year } 0\end{array}$ & $\begin{array}{l}\text { Credit Access } \\
\text { Year } 1\end{array}$ & $\begin{array}{l}\text { Credit Access } \\
\text { Year } 2\end{array}$ & $\begin{array}{l}\text { Credit Access } \\
\text { Year } 3\end{array}$ & $\begin{array}{l}\text { Credit Access } \\
\text { Year } 4\end{array}$ & $\begin{array}{l}\text { Credit Access } \\
\text { Year } 5\end{array}$ & $\begin{array}{l}\text { Credit Access } \\
\text { Year } 6\end{array}$ & $\begin{array}{l}\text { Credit Access } \\
\text { Year } 7\end{array}$ & $\begin{array}{l}\text { Credit Access } \\
\text { Year } 8\end{array}$ & $\begin{array}{l}\text { Credit Access } \\
\text { Year } 9\end{array}$ & $\begin{array}{l}\text { Credit Access } \\
\text { Year } 10\end{array}$ \\
\hline Female CEO & $\begin{array}{l}-0.102^{* \ldots * \cdots * k} \\
(0.032)\end{array}$ & $\begin{array}{l}-0.065^{*} \\
(0.037)\end{array}$ & $\begin{array}{l}-0.005 \\
(0.047)\end{array}$ & $\begin{array}{l}-0.007 \\
(0.056)\end{array}$ & $\begin{array}{l}-0.064 \\
(0.063)\end{array}$ & $\begin{array}{l}0.042 \\
(0.070)\end{array}$ & $\begin{array}{l}-0.012 \\
(0.081)\end{array}$ & $\begin{array}{l}-0.111 \\
(0.097)\end{array}$ & $\begin{array}{l}-0.126 \\
(0.111)\end{array}$ & $\begin{array}{l}-0.057 \\
(0.144)\end{array}$ & $\begin{array}{l}-0.293 \\
(0.208)\end{array}$ \\
\hline Equity & $\begin{array}{l}0.025^{* k *} \\
(0.009)\end{array}$ & $\begin{array}{l}-0.009 \\
(0.009)\end{array}$ & $\begin{array}{l}0.010 \\
(0.011)\end{array}$ & $\begin{array}{l}0.026 \\
(0.012)\end{array}$ & $\begin{array}{l}0.017 \\
(0.014)\end{array}$ & $\begin{array}{l}0.019 \\
(0.016)\end{array}$ & $\begin{array}{l}0.001 \\
(0.018)\end{array}$ & $\begin{array}{l}-0.003 \\
(0.020)\end{array}$ & $\begin{array}{l}-0.002 \\
(0.024)\end{array}$ & $\begin{array}{l}0.055 \\
(0.031)\end{array}$ & $\begin{array}{l}-0.008 \\
(0.044)\end{array}$ \\
\hline Year FE & Yes & Yes & Yes & Yes & Yes & Yes & Yes & Yes & Yes & Yes & Yes \\
\hline Industry FE & Yes & Yes & Yes & Yes & Yes & Yes & Yes & Yes & Yes & Yes & Yes \\
\hline Province FE & Yes & Yes & Yes & Yes & Yes & Yes & Yes & Yes & Yes & Yes & Yes \\
\hline \# observations & 28,762 & 20,421 & 13,707 & 10,142 & 8240 & 6620 & 5167 & 3930 & 2893 & 1796 & 957 \\
\hline Pseudo R2 & 0.0174 & 0.0133 & 0.0152 & 0.0160 & 0.0220 & 0.0209 & 0.0232 & 0.0298 & 0.0310 & 0.0664 & 0.0808 \\
\hline LR stat & $626.1^{* * * k}$ & $367.7^{\text {*** }}$ & $288.3^{\text {*决 }}$ & $224.5^{\text {*** }}$ & $249.9^{* \ldots * *}$ & $189.6^{* * *}$ & $164.0^{\text {*** }}$ & $156,9^{\text {k火k }}$ & 122.6 & $163.1^{* * *}$ & 107.0 \\
\hline $\begin{array}{l}\text { Odds Ratio } \\
\quad \text { Female CEO }\end{array}$ & 0.903 & 0.937 & 0.995 & 0.993 & 0.938 & 1.043 & 0.988 & 0.895 & 0.882 & 0.945 & 0.746 \\
\hline
\end{tabular}

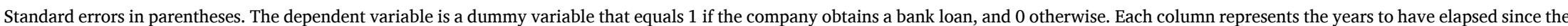

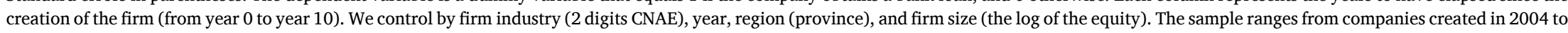
those created in 2014.

$$
\begin{aligned}
& { }_{* * * *} \mathrm{p}<0.01 . \\
& * \mathrm{p}<0.05 .
\end{aligned}
$$$$
\text { * } \mathrm{p}<0.10 \text {. }
$$ 
Table 5

Logit model on the probability of going into arrears after getting a bank loan.

\begin{tabular}{|c|c|c|c|c|c|c|c|c|c|c|c|}
\hline & (1) & (2) & (3) & (4) & (5) & (6) & (7) & (8) & (9) & (10) & (11) \\
\hline & $\begin{array}{l}\text { Non } \\
\text { Performing } \\
\text { Year 0 }\end{array}$ & $\begin{array}{l}\text { Non } \\
\text { Performing } \\
\text { Year 1 }\end{array}$ & $\begin{array}{l}\text { Non } \\
\text { Performing } \\
\text { Year } 2\end{array}$ & $\begin{array}{l}\text { Non } \\
\text { Performing } \\
\text { Year } 3\end{array}$ & $\begin{array}{l}\text { Non } \\
\text { Performing } \\
\text { Year } 4\end{array}$ & $\begin{array}{l}\text { Non } \\
\text { Performing } \\
\text { Year } 5\end{array}$ & $\begin{array}{l}\text { Non } \\
\text { Performing } \\
\text { Year } 6\end{array}$ & $\begin{array}{l}\text { Non } \\
\text { Performing } \\
\text { Year } 7\end{array}$ & $\begin{array}{l}\text { Non } \\
\text { Performing } \\
\text { Year } 8\end{array}$ & $\begin{array}{l}\text { Non } \\
\text { Performing } \\
\text { Year } 9\end{array}$ & $\begin{array}{l}\text { Non } \\
\text { Performing } \\
\text { Year } 10\end{array}$ \\
\hline Female CEO & $\begin{array}{l}-0.139 \text { ** } \\
(0.068)\end{array}$ & $\begin{array}{l}-0.133^{*} \\
(0.073)\end{array}$ & $\begin{array}{l}-0.027 \\
(0.085)\end{array}$ & $\begin{array}{l}-0.036 \\
(0.098)\end{array}$ & $\begin{array}{l}-0.054 \\
(0.116)\end{array}$ & $\begin{array}{l}0.021 \\
(0.131)\end{array}$ & $\begin{array}{l}0.093 \\
(0.156)\end{array}$ & $\begin{array}{l}-0.083 \\
(0.188)\end{array}$ & $\begin{array}{l}0.148 \\
(0.230)\end{array}$ & $\begin{array}{l}0.181 \\
(0.309)\end{array}$ & $\begin{array}{l}-1.156 \\
(0.737)\end{array}$ \\
\hline Debt/equity & $\begin{array}{l}0.105^{* * *} \\
(0.016)\end{array}$ & $\begin{array}{l}0.093^{* * *} \\
(0.016)\end{array}$ & $\begin{array}{l}0.106 * * * \\
(0.025)\end{array}$ & $\begin{array}{l}0.052^{* *} \\
(0.021)\end{array}$ & $\begin{array}{l}0.030 \\
(0.024)\end{array}$ & $\begin{array}{l}0.035 \\
(0.028)\end{array}$ & $\begin{array}{l}-0.107^{* * *} \\
(0.034)\end{array}$ & $\begin{array}{l}-0.048 \\
(0.039)\end{array}$ & $\begin{array}{l}-0.156^{* * *} \\
(0.048)\end{array}$ & $\begin{array}{l}-0.227^{* * *} \\
(0.061)\end{array}$ & $\begin{array}{l}-0.533^{* * *} \\
(0.120)\end{array}$ \\
\hline Year FE & Yes & Yes & Yes & Yes & Yes & Yes & Yes & Yes & Yes & Yes & Yes \\
\hline Industry FE & Yes & Yes & Yes & Yes & Yes & Yes & Yes & Yes & Yes & Yes & Yes \\
\hline Province FE & Yes & Yes & Yes & Yes & Yes & Yes & Yes & Yes & Yes & Yes & Yes \\
\hline \# observations & 23,789 & 15,973 & 10,784 & 7994 & 6282 & 4866 & 3559 & 2671 & 1812 & 1009 & 387 \\
\hline Pseudo R2 & 0.1016 & 0.0827 & 0.0748 & 0.0646 & 0.0591 & 0.0568 & 0.0592 & 0.0753 & 0.1044 & 0.1373 & 0.2374 \\
\hline LR stat & $1421.8^{* * *}$ & $945.8^{* * *}$ & $639.4^{* * *}$ & $423.4^{* * *}$ & $287.1^{* * *}$ & $202.7^{* \cdots * k}$ & $151.0^{* * *}$ & $145.7^{* * *}$ & $132.7^{* * * k}$ & $100.5^{* *}$ & $66.0^{* * *}$ \\
\hline $\begin{array}{c}\text { Odds ratio } \\
\text { Female } \\
\text { CEO }\end{array}$ & $0.861^{* *}$ & $0.876^{*}$ & 0.973 & 0.965 & 0.947 & 1.021 & 1.097 & 0.920 & 1.159 & 1.199 & 0.315 \\
\hline
\end{tabular}

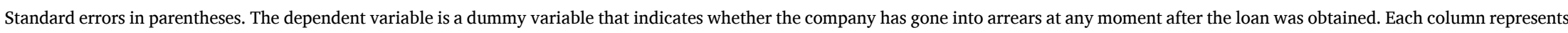

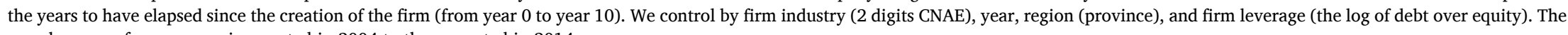
sample ranges from companies created in 2004 to those created in 2014.

$\begin{array}{rl}* * * * & \mathrm{p}<0.01 \\ \mathrm{p} & <0.05\end{array}$

$\begin{aligned} * \mathrm{p} & <0.05 \\ \mathrm{p} & <0.10 .\end{aligned}$ 
Table 6

Logit models on the probability of demanding a loan, obtaining one and going into arrears for construction and commerce companies.

\begin{tabular}{|c|c|c|c|c|c|c|c|c|c|c|}
\hline & \multicolumn{5}{|c|}{ Construction and Real Estate Developers } & \multicolumn{5}{|c|}{ Commerce and Restaurants } \\
\hline & Year 0 & Year 1 & Year 2 & Year 3 & Year 4 & Year 0 & Year 1 & Year 2 & Year 3 & Year 4 \\
\hline & \multicolumn{10}{|c|}{ Credit Demand } \\
\hline Female CEO & $\begin{array}{l}-0.054 \\
(0.055)\end{array}$ & $\begin{array}{l}-0.100^{*} \\
(0.060)\end{array}$ & $\begin{array}{l}-0.074 \\
(0.069)\end{array}$ & $\begin{array}{l}-0.197^{\text {** }} \\
(0.082)\end{array}$ & $\begin{array}{l}-0.205^{* *} \\
(0.091)\end{array}$ & $\begin{array}{l}-0.171^{\text {*小*k }} \\
(0.037)\end{array}$ & $\begin{array}{l}-0.104^{* *} \\
(0.041)\end{array}$ & $\begin{array}{l}-0.260^{* \cdots * k} \\
(0.049)\end{array}$ & $\begin{array}{l}-0.237^{* \cdots *} \\
(0.056)\end{array}$ & $\begin{array}{l}-0.229^{\text {k** }} \\
(0.061)\end{array}$ \\
\hline \# observations & 13,412 & 11,431 & 9157 & 7426 & 6228 & 18,313 & 15,803 & 12,180 & 9841 & 8569 \\
\hline \multirow[t]{2}{*}{ OR Female CEO } & 0.948 & $0.905^{\star}$ & 0.929 & $0.821^{* * *}$ & $0.814^{* *}$ & $0.843^{\text {*** }}$ & $0.901^{* *}$ & $0.771^{* * *}$ & $0.789^{* * *}$ & $0.795^{* * *}$ \\
\hline & \multicolumn{10}{|c|}{ Credit Access } \\
\hline Female CEO & $\begin{array}{l}-0.138 \\
(0.087)\end{array}$ & $\begin{array}{l}-0.059 \\
(0.088)\end{array}$ & $\begin{array}{l}-0.097 \\
(0.104)\end{array}$ & $\begin{array}{l}-0.064 \\
(0.124)\end{array}$ & $\begin{array}{l}-0.026 \\
(0.141)\end{array}$ & $\begin{array}{l}-0.210^{* * *} \\
(0.061)\end{array}$ & $\begin{array}{l}-0.144 * * \\
(0.067)\end{array}$ & $\begin{array}{l}0.084 \\
(0.084)\end{array}$ & $\begin{array}{l}0.064 \\
(0.096)\end{array}$ & $\begin{array}{l}-0.098 \\
(0.105)\end{array}$ \\
\hline \# observations & 5952 & 4808 & 3589 & 2623 & 1996 & 7176 & 5605 & 3904 & 2997 & 2550 \\
\hline \multirow[t]{2}{*}{ OR Female CEO } & 0.894 & 1.022 & 0.977 & 0.926 & 0.988 & $0.811^{* * *}$ & $0.866^{* *}$ & 1.088 & 1.066 & 0.907 \\
\hline & \multicolumn{10}{|c|}{ Non-Performing Loans } \\
\hline Female CEO & $\begin{array}{l}-0.197 \\
(0.138)\end{array}$ & $\begin{array}{l}-0.134 \\
(0.136)\end{array}$ & $\begin{array}{l}-0.268 \\
(0.170)\end{array}$ & $\begin{array}{l}-0.308 \\
(0.213)\end{array}$ & $\begin{array}{l}0.148 \\
(0.268)\end{array}$ & $\begin{array}{l}-0.298^{* *} \\
(0.130)\end{array}$ & $\begin{array}{l}-0.326^{* *} \\
(0.138)\end{array}$ & $\begin{array}{l}-0.150 \\
(0.159)\end{array}$ & $\begin{array}{l}-0.371^{*} \\
(0.198)\end{array}$ & $\begin{array}{l}-0.237 \\
(0.239)\end{array}$ \\
\hline \# observations & 5216 & 4654 & 2903 & 1881 & 1259 & 6849 & 4822 & 3034 & 2155 & 1570 \\
\hline OR Female CEO & 0.821 & 0.875 & 0.765 & 0.735 & 1.160 & $0.743^{* *}$ & $0.722^{* *}$ & 0.861 & $0.690^{*}$ & 0.789 \\
\hline
\end{tabular}

Standard errors in parentheses.

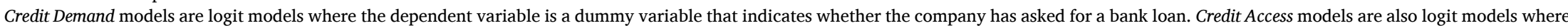

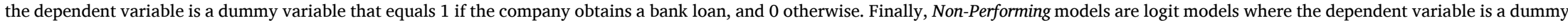

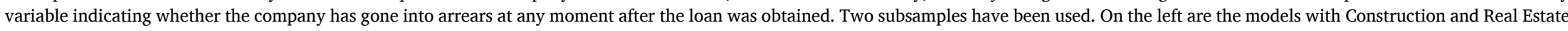

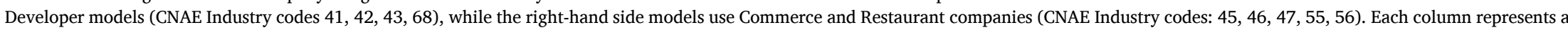

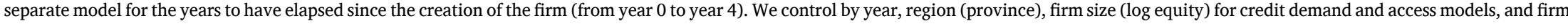
leverage (the log of debt over equity) for non-performing models. The sample spans companies created between 2004 and 2014.

$$
\begin{aligned}
& * * * \quad \mathrm{p}<0.01 . \\
& { }^{* *} \mathrm{p}<0.05 \\
& \mathrm{p}<0.10
\end{aligned}
$$


Table 7

Logit models on the probability of going into arrears two years after obtaining a bank loan.

\begin{tabular}{llll}
\hline & Arrears & & \\
\cline { 2 - 4 } & Year 0 & Year 1 & Year 2 \\
\hline Female CEO & $-0.184^{* *}$ & $-0.140^{*}$ & -0.0852 \\
& $(0.082)$ & $(0.078)$ & $(0.096)$ \\
Debt/equity & $-0.622^{* * *}$ & $-0.882^{* * *}$ & $-2.440^{* * *}$ \\
& $(0.207)$ & $(0.280)$ & $(0.545)$ \\
Year FE & Yes & Yes & Yes \\
Province FE & Yes & Yes & Yes \\
Industry FE & Yes & Yes & Yes \\
\# observations & 22,058 & 15,867 & 9912 \\
LR stat & $438.86^{* * *}$ & $407.07^{* * *}$ & $434.52^{* * *}$ \\
\hline
\end{tabular}

Standard errors in parentheses. The dependent variable is a dummy variable that indicates whether the company has gone into arrears in the following two years after the loan was obtained. Each column represents the years to have elapsed since the creation of the firm (from year 0 to year 2). We control by firm industry (2 digits CNAE), year, region (province), and firm leverage (the log of debt over equity). The sample spans companies created between 2004 and 2014.

**** $\mathrm{p}<0.01$.

${ }^{* * *} \mathrm{p}<0.05$.

* $\mathrm{p}<0.10$.

Table 8

Tobit models on the amount of money lost for each bank loan granted.

\begin{tabular}{llll}
\hline & Loan Loss & & \\
\cline { 2 - 4 } & Year 0 & Year 1 & Year 2 \\
\hline Female CEO & $-1.332^{* *}$ & $-1.258^{*}$ & -1.178 \\
& $(0.679)$ & $(0.681)$ & $(0.814)$ \\
Debt/equity & $-7.215^{* * *}$ & $-7.103^{* * *}$ & $-14.99^{* * *}$ \\
& $(1.62)$ & $(1.88)$ & $(3.45)$ \\
Year FE & Yes & Yes & Yes \\
Province FE & Yes & Yes & Yes \\
Industry FE & Yes & Yes & Yes \\
\# observations & 21,331 & 15,537 & 9875 \\
LR stat & $1268.8^{* * *}$ & $946.6^{* * *}$ & $650.9^{* * *}$ \\
\hline
\end{tabular}

Standard errors in parentheses. The dependent variable is the amount of money the bank fails to receive after granting a loan. Tobit model censored at zero for loans where there has been no loss. Each column represents the years to have elapsed since the creation of the firm (from year 0 to year 2). We control by firm industry (2 digits CNAE), year, region (province), and firm leverage (the log of debt over equity). The sample spans companies created between 2004 and 2014.

$\mathrm{p}<0.01$.

** $\mathrm{p}<0.05$.

$* \mathrm{p}<0.10$.

Table 9

Cox Regression on the hazard of default.

\begin{tabular}{llll}
\hline & Hazard model & & Year 2 \\
\cline { 2 - 4 } & Year 0 & Year 1 & -0.249 \\
\hline Female CEO & $-0.362^{* * *}$ & -0.089 & $(0.155)$ \\
Debt/equity & $(0.137)$ & $(0.117)$ & $-1.901^{* *}$ \\
& $-0.823^{* * *}$ & $-0.686^{* *}$ & $(0.746)$ \\
Year FE & $(0.355)$ & $(0.409)$ & Yes \\
Province FE & Yes & Yes & Yes \\
Industry FE & Yes & Yes & Yes \\
\# observations & Yes & Yes & 9130 \\
LR stat & 20,593 & 14,556 & $278.74^{*}$ \\
\hline
\end{tabular}

Standard errors in parentheses. Cox regression hazard model where the dependent variable is the time to default since the loan is granted, censored for cases where there has been no default. Each column represents the years to have elapsed since the creation of the firm (from year 0 to year 2). We control by firm industry (2 digits CNAE), year, region (province), and firm leverage (the log of debt over equity). The sample spans companies created between 2004 and 2014.

**** $\mathrm{p}<0.01$.

** $\mathrm{p}<0.05$.

* $\mathrm{p}<0.10$. 


$$
\lambda(\mathrm{t} \mid X)=\lambda_{0}(\mathrm{t}) \cdot \exp \cdot\left(\beta_{y} \cdot \text { Female }_{i}+\gamma_{y} \cdot \text { Debt } / \text { Equity }_{\text {iy }}+\delta_{\text {year }}+\vartheta_{\text {Industry }}+\vartheta_{\text {Province }}\right)
$$

All three approaches produce the same result we observed for the default models of Eq. (3) in section 4.3. That is, firms run by women perform better than those run by men for loans obtained in the year the firm was created, although there is no performance difference for latter years.

\subsection{Panel data models}

As a final robustness analysis, we have taken advantage of the fact that we are observing the same companies in different years. This allows us to estimate panel data models for all three logit models (credit demand, access, and default). In these cases, we include an interaction variable to single out the cases of companies run by women in the year the company was set up. Results for both fixed and random firm effects are shown in Table 10.

The likelihood of securing a loan is lower for companies run by a woman in the first year, although those who do obtain one are less likely to default. However, the main caveat of panel models (especially for fixed effects) for this analysis is that several firms must be dropped from the analysis due to lack of variability in the outcome within firms.

\section{Conclusions}

This paper examines the presence of discrepancies in credit demand, credit access and credit performance by firms run by female and male directors. We confirm that women-led companies are less likely than men-led companies to ask for a loan. This result is compatible both with the potential higher risk aversion of women as well as self-exclusion due to an anticipation by the female administrator of a lower probability of obtaining a loan, which makes them desist from initially seeking one.

We observe that women-led companies who ask for a loan in the founding year are less likely to obtain a loan (that is, even after controlling for their lower credit demand). However, this credit access gap disappears after the second year the firm is created. One possible explanation for this outcome is that when the company started out, the lack of information on its financial record led the lender to use the personal characteristics of the director, such as gender, to proxy their new company creditworthiness in an attempt to minimize the cost of gathering more directly relevant information about the borrower's business plan. In that context, if women-led companies have, on average, less creditworthiness than those men-led companies, whatever the reason (women entrepreneurs may be younger, have less business experience or may prioritize their work-life balance), women would face a handicap that reduces the likelihood of getting a bank loan. However, once the company has run for long enough, banks may apply more formal credit scoring models using balance sheet and profit and loss accounts. Personal characteristics then become less relevant, until borrower gender is no longer a factor in loan decision making.

As we find no bias for older firms, we can rule out the presence of Beckerian taste-based discrimination, since having its roots in prejudices and cultural beliefs does not tend to disappear in the presence of additional financial information. However, the lower proportion of credit access among younger firms run by women might be caused by two alternative explanations, a rational one (i.e., statistical discrimination), or an unconscious and less intentional one (i.e., implicit double standards). Through our analysis of credit performance, we have been able to disentangle these two alternative explanations. Our results show that women-led companies who experienced tougher credit access in the founding year and are less likely to go into default, which would point to some kind of nonrational bias. Indeed, this result signals the existence of an implicit double standard rather than to statistical discrimination.

Table 10

Panel data models on credit demand, credit access and credit default.

\begin{tabular}{|c|c|c|c|c|c|c|c|c|c|c|c|c|}
\hline \multirow[b]{2}{*}{ Woman*Start } & \multicolumn{3}{|c|}{ Credit Demand } & \multicolumn{4}{|c|}{ Credit Access } & \multicolumn{5}{|c|}{ Credit Default } \\
\hline & 0.081 & $* * *$ & $\begin{array}{l}-0.139 \\
(0.027)\end{array}$ & $* * *$ & $\begin{array}{l}-0.155 \\
(0.074)\end{array}$ & $* * *$ & $\begin{array}{l}-0.111 \\
(0.041)\end{array}$ & $* * *$ & $\begin{array}{l}-2.346 \\
(0.445)\end{array}$ & $* * *$ & $\begin{array}{l}-0.331 \\
(0.179)\end{array}$ & $*$ \\
\hline Woman*Start +1 & 0.084 & $* * *$ & $\begin{array}{l}-0.141 \\
(0.029)\end{array}$ & $* * *$ & $\begin{array}{l}-0.060 \\
(0.071)\end{array}$ & & $\begin{array}{l}-0.046 \\
(0.043)\end{array}$ & & $\begin{array}{l}-1.431 \\
(0.420)\end{array}$ & $* * *$ & $\begin{array}{l}-0.239 \\
(0.205)\end{array}$ & \\
\hline Equity & 0.152 & $* * *$ & $\begin{array}{l}0.146 \\
(0.003)\end{array}$ & $* * *$ & $\begin{array}{l}0.067 \\
(0.014)\end{array}$ & $* * *$ & $\begin{array}{l}0.012 \\
(0.005)\end{array}$ & $* *$ & & & & \\
\hline Debt & & & & & & & & & $\begin{array}{l}-6.988 \\
(1.10)\end{array}$ & & $\begin{array}{l}-0.004 \\
(0.007)\end{array}$ & \\
\hline Firm Effects & Fixed & & Random & & Fixed & & Random & & Fixed & & Random & \\
\hline Year Effects & Yes & & Yes & & Yes & & Yes & & Yes & & Yes & \\
\hline Observations & 193,706 & & 282,535 & & 48,445 & & 90,575 & & 2129 & & 62,384 & \\
\hline Firms & 35,226 & & 66,316 & & 14,201 & & 43,735 & & 614 & & 39,290 & \\
\hline Wald/LR Test & 2211.64 & $* * *$ & 7226.88 & $* * *$ & 2411.05 & $* * *$ & 5256.83 & $* * *$ & 123.3 & $* * *$ & 844.32 & $* * *$ \\
\hline
\end{tabular}

Credit Demand models are logit models where the dependent variable is a dummy variable that indicates whether the company has asked for a bank loan. Credit Access models are also logit models where the dependent variable is a dummy variable that equals 1 if the company obtains a bank loan, and 0 otherwise. Finally, Credit Default models are logit models where the dependent variable is a dummy variable indicating whether the company has gone into arrears at any moment after the loan was obtained. Women*Start is the interaction between companies with a female CEO and the year the company was created. Women *Start +1 is the interaction between companies with a female CEO and one year after the creation of the company. Wald Test results are reported for Firm Fixed Effect Logit regressions, and Likelihood Ratio Test for Firm Random Effect Logit regressions. 
These results have two main consequences. Firstly, implicit double standards suggest that credit allocation among start-ups (i.e., young firms) is not efficient. Correcting this bias would imply that women-led companies would be more likely to grow in the initial years of the firm and so not lag behind men-led companies for the rest of the company's life. Our findings suggest that financial institutions could improve the quality of their asset (credit) portfolio if they corrected such unconscious bias. Secondly, contrary to tastebased and statistical discrimination, implicit discrimination can be more easily corrected. Once actors acknowledge the existence of implicit discrimination, they are likely to correct it voluntarily since this discrimination goes against their own interests. In the case of credit scoring for entrepreneurs, one likely cause of implicit discrimination is that credit scoring methodologies (both qualitative and quantitative) are calibrated with the most common group (in this case, male entrepreneurs), but the relationship between the entrepreneur's characteristics and the credit quality of the company they run might differ between women entrepreneurs and men entrepreneurs (e.g., due to different risk appetites observed in credit demand). Therefore, we advise banks to review their credit scoring processes to explore whether the interaction of the traditional factors/variables and gender would improve credit performance.

Apart from the factual result concerning the situation in the credit market, the paper also contributes in the methodology used, in that it disentangles different types of discrimination by separating credit market supply and demand factors. Once these are isolated, we were able to identify not only whether there is some kind of discrimination, but also the actual type, by looking at performance. The same procedure could be used for other situations, such as hiring decisions, or any other evaluation process.

\section{Acknowledgements}

The authors benefited from the helpful comments of Steven Ongena, Sergio Mayordomo, Belén Nieto, Gonzalo Rubio, Tano Santos, Almudena Sevilla, Siri Terjesen, and participants attending research seminars at -Banco de España, Zaragoza, Murcia and CEU Universities, as well as conferences of EURAM, ICGS, Academy of Management and EFiC. This research has been funded by (i) FEF-IEAF with the Research Award Antonio Dionis Soler 2019; (ii) the Spanish Government (AEI/FEDER-UE) (ref. FEM2017-83006-R) (iii) USPCEU-Mutua Madrileña (060516-USPMM-02/17) (iv) Spanish Government (ref. ECO2015-65826-P) (v) Spanish Government (ref. ECO2017-85356-P).

\section{References}

Alesina, A.F., Lotti, F., Mistrulli, P.E., 2013. Do women pay more for credit? Evidence from Italy. J. Eur. Econ. Assoc. 11 (S1), $45-66$.

Aristei, D., Gallo, M., 2016. Does gender matter for firms' access to credit? Evidence from international data. Financ. Res. Lett. 18 , 67-75.

Asiedu, E., Freeman, J.A., Nti-Addae, A., 2012. Access to credit by small business: how relevant are race, ethnicity, and gender? Am. Econ. Rev. Pap. Proc. 102 (3), $532-537$.

Beck, T., Demirguc-Kunt, A., 2006. Small and medium-size enterprises: access to finance as a growth constraint. J. Bank. Financ. 30 (11), $2931-2943$.

Beck, T., Bert, P., Madestam, A., 2018. Sex and credit: is there a gender Bias in lending? J. Bank. Financ. 87, 380-396.

Becker, G., 1957. The Economics of Discrimination, 2nd ed. University of Chicago Press, Chicago, IL.

Bellucci, A., Borisov, A., Zazzaro, A., 2010. Does gender matter in bank-firm relationships? Evidence from small business lending. J. Bank. Financ. 34 (12), $2968-2984$.

Berger, A.N., Udell, G.F., 2002. The economics of small business finance: the roles of private equity and debt markets in the financial growth cycle. J. Bank. Financ. 22, 613-673.

Bertrand, M., Chugh, D., Mullainathan, S., 2005. Implicit discrimination. Am. Econ. Rev. 95 (2), $94-98$.

Blanchflower, D.G., Levine, P.B., Zimmerman, D.J., 2003. Discrimination in the small-business credit market. Rev. Econ. Stat. 85 (4), $930-943$.

Cabral, L.M.B., Mata, J., 2003. On the evolution of the firm size distribution: facts and theory. Am. Econ. Rev. 93 (4), 1075-1090.

Cavalluzzo, K., Wolken, J., 2005. Small business loan turndowns, personal wealth, and discrimination. J. Bus. 78 (6), $2153-2178$.

Cole, R.A., Mehran, H., 2009. Gender and the Availability of Credit to Privately Held Firms: Evidence from the Surveys of Small Business Finances. Federal Reserve Bank of New York Staff Reports. (No. 383).

Coleman, S., Robb, A., 2009. A comparison of new firm financing by gender: evidence from the Kaufman firm survey data. Small Bus. Econ. $33,397-411$.

Cox, D.R., 1972. Regression models and life-tables. J. R. Stat. Soc. Ser. B 34 (2), 187-202.

Galli, E., Rossi, S.P.S., 2016. Bank credit access and gender discrimination: some stylized facts. In: Rossi, Malavasi, R. (Eds.), (2016): Financial Crisis, Bank Behaviour and Credit. Springer International Publishing, Switzerland, pp. 111-123.

García-Posada, M., Mora-Sanguinetti, J.S., 2014. Are there alternatives to bankruptcy? A study of small business distress in Spain. SERIEs 5 (2-3), 287-332.

Jianakoplos, N.A., Bernasek, A., 1998. Are women more risk averse? Econ. Inq. 36, 620-630.

Jiménez, G., Ongena, S., Peydró, J.L., Saurina, J., 2012. Credit supply and monetary policy: identifying the bank balance-sheet channel with loan applications. Am. Econ. Rev. 102 (5), 2301-2326.

Jiménez, G., Ongena, S., Peydró, J.L., Saurina, J., 2014. Hazardous times for monetary policy: what do twenty-three million Bank loans say about the effects of monetary policy on credit risk-taking? Econometrica 82 (2), 463-505.

Jiménez, G., Ongena, S., Peydró, J.L., Saurina, J., 2017. Macroprudential policy, countercyclical Bank capital buffers, and credit supply: evidence from the Spanish dynamic provisioning experiments. J. Polit. Econ. 125 (6), 2126-2177.

Marlow, S., Patton, D., 2005. All credit to men? Entrepreneurship, finance, and gender. Entrep. Theory Pract. 29, 717-735.

Moro, A., Wisniewski, T.P., Mantovani, G.M., 2017. Does a manager's gender matter when accessing credit? Evidence from European data. J. Bank. Financ. 80, 119-134.

Muravyev, A., Talavera, O., Shäfer, D., 2009. Entrepreneurs' gender and financial constraints: evidence from international data. J. Comp. Econ. 37 (2), 270-286. Ongena, S., Popov, A., 2016. Gender bias and credit access. J. Money Credit Bank. 48 (8), 1691-1724.

Phelps, E.S., 1972. The statistical theory of racism and sexism. Am. Econ. Rev. 62, 659-661.

Robb, A., Wolken, J., 2002. Firm, Owner, and Financial Characteristics: Differences between Female and Male-Owned Small Businesses, Federal Reserve Finance and Economics Discussion Series, 2002-18.

Schubert, R., Brown, M., Gysler, M., Brachinger, H.W., 1999. Financial decision-making: are women really more risk-averse? Am. Econ. Rev. 89 (2), $381-385$.

Stefani, M.L., Vacca, V.P., 2013. Credit access for Female Firms: Evidence from a Survey on European SMEs. Bank of Italy Occasional Paper, n.176.

Sunden, A.E., Brian, J., 1998. Gender differences in the allocation of assets in retirement savings plans. Am. Econ. Rev. Papers Proceed. 88, $207-211$.

Tobin, J., 1958. Estimation of relationships for limited dependent variables. Econometrica 26 (1), 24-36.

Treichel, M.Z. And J.A. Scott, 2006. Women-owned businesses and access to bank credit: evidence from three surveys since 1987. Ventur. Cap. 8 (1), 51-67. 